\title{
MINECRAFTEDU - VAN-E RELEVANCIÁJA A VIDEÓJÁTÉKOKKAL TÖRTÉNŐ OKTATÁSNAK?
}

\section{Szerzők:}

Győri Krisztina

Debreceni Egyetem

Papp Dávid

Debreceni Egyetem

Első szerző e-mail címe:

gyorikrisztina97@gmail.com

\section{Lektorok:}

Csukonyi Csilla $(\mathrm{PhD})$

Debreceni Egyetem

Mező Ferenc (PhD)

Eszterházy Károly Egyetem

...és további két anonim lektor

\begin{abstract}
Absztrakt
Gyorsan változó környezetünk folyamatos innovációt igényel és ez nincs máshogy az oktatással sem. Mindennek köszönhetően több digitális eszköz vívta ki helyét a tanítástanulás színterén is. Az IKT eszközök alkalmazása, azonban alapvetően nem hozza meg a csodát az oktatásban, többek között azért is, mert a különféle digitális eszközök szoftveres felkészültséget és szakértelmet igényelnek. Ezeken a speciálisan oktatásra szánt programokon kívül a videójátékok oktatási célra való felhasználása is egyre nagyobb figyelmet kapott, viszont még így is kevés szakirodalmat tudhat ez a terület magáénak. Kutatásunk célja az volt, hogy megnevezzük az oktatásra alkalmas videó-játékoknak a jellemzőit (Pásztor, 2013), továbbá kipróbáljunk magyar mintán egy már gyakorta oktatásban alkalmazott videójátékot, a Minecraftot. Munkánk során egy videó-játékozó és egy nem videójátékozó (kontroll) csoport került összevetésre. A csopor-tokat 3. osztályos tanulók alkották. A kutatás során bebizonyosodott a szakirodalom azon álláspontja, miszerint a videójátékokkal való oktatás minőségében lehet olyan eredményes, mint egy hagyományos módszerekkel megtartott óra. Emellett kiderült, hogy a videójátékokkal való oktatás a közhiedelemmel ellentétben nem motiválóbb a gyermekek számára, mint egy hagyományos osztálytermi óra, hanem sokkal inkább kizökkenti a tanulót a szürke hétköznapokból.
\end{abstract}

Kulcsszavak: IKT, videójátékok, oktatás, Minecraft, MinecraftEDU

Diszciplína: pszichológia, pedagógia, informatika 


\section{Abstract \\ MINECRAFTEDU - DOES EDUCATION WITH VIDEOGAMES HAVE RELEVANCE?}

Our quickly changin environment needs continuous innovation and this is true in education as well. Thanks to all this more digital appliancies achieved their place in the scene of teaching and learning. The use of ICT appliancies however does not make miracles in education, that is among other because the different digital appliancies demand preparedness and expertise in software. Besides the programmes made specifically for education, the educational use of video games have recieved even more attention, nonetheless this type of topic has a little amount of literature. The aim of our study was to name the attributes of adequate educational video games (Pásztor, 2013). furthermore to test on a hungarian sample a video game (Minecraft) which is frequently used in education. In our work we compare a video game playing group with a non-video game playing group as control. The groups constituted by students from third grade. By this research that standpoint of the literature was verified, which suggested that education through video games could be in quality as effective, as a lesson with traditional methods. In addition as it turned out, education with video games contrary to the popular belief is not more motivating for the children compared to a traditional classroom lesson, but dislocate the student from the monotonous every day life.

Keywords: ICT, video games, education, Minecraft, MinecraftEDU

Disciplines: psychology, pedagogy, informatics

Győri Krisztina és Papp Dávid (2020): MinecraftEDU - Van-e relevanciája a videójátékokkal történő oktatásnak?. Mesterséges intelligencia - interdiszciplináris folyóirat, II. évf. 2020/2. szám. 23-33. doi: 10.35406/MI.2020.2.23

A technológiai fejlődés az élet minden színterére hatással van. A gyors és néha már követhetetlen innováció alakítja társadalmunkat és világunkat. Ezen fejlődés eredményeképpen az oktatásban egyre nagyobb igény mutatkozik az IKT felkészültségre, ami kihívást jelenthet akár a legelhivatottabb pedagógusok számára is, ugyanis a számítógépek és mobileszközök alkalmazása önmagában nem teszi hatásosabbá az oktatást (Kárpáti, 2003). Annak érdekében, hogy a pedagógusok valóban sikeresek legyenek a digitális eszközökkel egy paradigmaváltáson kellett átesniük (Molnár, 2011), a jelenben pedig az eddigieknél is nagyobb váltás ütötte fel a fejét a videójátékok oktatásban való alkalmazásának a térhódításával. 


\section{Videójátékok az oktatásban}

A továbbhaladáshoz fontosnak véljük tisztázni elsőként is azt hogy, mi is a videójáték. A videojáték egy komplex fogalom, amely magába foglal minden olyan játékot, amely valamilyen programnyelv, illetve videójáték motor segítségével készült el, megannyi platform (számítógép/laptop, konzolok és/vagy mobiltelefon) legalább egyikén elérhetőek, általános tulajdonságaikat tekintve pedig rendelkeznek szabályozó, keretrendszer-rel, minimum egy kitűzött céllal, a játékos felé visszajelző rendszerrel, végül önkéntes alapon működnek (Bányai és Fülöp, 2015; McGonigal, 2011).

Sokak a videójátékok egyik legnagyobb erejét, azok motivációra kifejtett hatásukban látják. Ryan, Rigby és Przybylski 2006os kutatásuk folyamán a videó-játékok okozta motivációs vonzást az öndeterminációs elméletre alapozva közelítették meg. Az elmélet Deci és Ryan (2000) nevéhez kötődik, és az elmélet lényege, hogy a motiváció és maga a motiváltság három velünk született pszic-hológiai szükséglet teljesüléseként nyilvá-nul meg (az autonómia, a kötődés és a kompetencia). A tevékenység végrehajtására az elmélet alapján akkor leszünk motiváltak, ha kellően illeszkedik ezen szükségletekhez, így a személy önállónak és hozzáértőnek érezheti magát, miközben a tevékenység által másokkal kötődni, kapcsolódni képes. A kutatók feltételezése alapján a videojátékok az előbbiekben részletezett három pszichológiai szükséglet megfelelő szintű kielégítésére alkalma- sak lehetnek. A kutatás négy vizsgálatot ölelt fel, melyek a számítógépes játékok adta környezetre, illetve a ,gamer" kontextusra irányultak. Az eredmények alapján az egyéni játékokban a kompetencia és autonómia érzése, illetve többszemélyes játék esetén a más játékosokhoz való kötődés érzésével kiegészülve a játékkal való elégedettségre, a későbbi játék esélyére és a motiváltságra pozitív hatást gyakoroltak.

Az intuitív irányítás egy olyan videojáték jellemző, amely kifejezett jelentőséggel van a játék-élménynek, illetve az játékban átélt autonómiaérzésnek a növelésére. Az autonómia és a kompetencia megélése pozitívan kapcsolódott az egyén játékot követő hangulatához. A videójátékozással töltött idő mennyiség pozitívan kapcsolódott a teljesítmény, illetve a kötődés mértékéhez. A jelenlétet és bevonódást akkor tudja leginkább elérni egy játék, ha a játékos magára a játékra tud koncentrálni, nem az adott játékmechanikára, illetve ha a játék megfelelően teljesíti a játékos pszichológiai szükségleteit. Azonban fon-tos azt is figyelembe venni, hogy a telje-sítés motívumára való nagyobb hangsúly fektetése negatív játékot követő hangulattal és egyéb negatív utóhatásokkal társulhat. Összegezve a videójátékozásnak való kitettségnek egyáltalán nem, vagy kis mértékben volt hatása a pozitív vagy negatív irányú hangulatváltozásra, a résztvevők éreztek egyfajta fáradtságot, de ezt kiegyensúlyozta a pszichológiai szükségletek megfelelő mértékű teljesülése. 
Több korábbi kutatás is foglalkozott a videojátékokkal történő oktatás, illetve annak motiváló erejének megvizsgálásával (Sitzmann, 2011; Pásztor, 2013; Wouters és mtsai, 2013) és eredményül arra jutottak, hogy az oktatás adta kontextusban a videójátékozásnak nincs nagyobb motiváló ereje az egyéb pedagógiai módszerekhez viszonyítva. E mögött több ok is állhat, egyrészről nem az adott tanuló választja meg az oktatás során alkalmazott video-játékot, másrészről a játékkal töltött idő mennyiségét szintén nem a tanuló befolyá-solja, így a kontroll érzése megszűnik (Wouters és mtsai, 2013), végül a videójátékok során tapasztalt flow érzés („game flow”) ilyen esetben nem tud teret nyerni, mivel a játékhoz általában nem szorosan kapcsolódnak az elsajátí-tandó ismeretek, amelyek kizökkenthetik így a tanulókat (Pásztor, 2013).

Mindezek alapján összefoglalhatjuk azt, hogy az oktatásra alkalmas, annak eredményességét elősegítő videójátékok esetében fontos, hogy ne legyenek grafikai elemekben túl gazdagok, túlságosan megterhelőek a diákok számára, kevés audiovizuális elemmel rendelkezzenek, mindazonáltal kellően reprezentatívak és megfelelően modellezettnek kellenek, hogy legyenek. Ezen követelményeknek a gyermekek körében elterjedt videójáték, a Minecraft megfelel, ezt a tényt, pedig maga a játék gyártója is felfedezte, ugyanis 2016 novemberében egy oktatásra alkal-mas változatot készítettek el a játékból.

\section{MinecraftEDU}

\section{A Minecraft videójáték bemutatása}

Azonban, mielőtt a MinecraftEDU oktatási mód lehetőségeit részleteznénk, fontosnak véljük az adott videójátéknak az átfogó ismertetését. A Minecraft játékot a svéd Mojang cég készítette 2009-ben, amelyet Java programozási nyelven írtak meg. A videójáték nagy sikert aratott a világon, így hamarosan az Apple IOS és az Andorid készülékeken is megjelent, aminek köszönhetően mára már számítógépen, mobilkészülékeken, de akár konzolokon is lehet Minecraftozni (Short, 2012). A videójáték tematikája alapvetően a kreativitás és az építés köré rendeződött, így joggal nevezik úgy a Minecraftot, mint digitális legót. A világ könnyedén a felhasználó kedve szerint alakítható. A videójátékok ezen típusát, pedig a piac „sand boksz" játékoknak nevezi. A Mincraft játék (ahogyan a fentiekben is utaltunk rá) építésre alkalmas, így legóhoz hasonlatos blokkokból áll, amelyek a pixelekhez hasonlatosak. Ezek a blokkok a tér minden irányában egymásra helyezhetők, így pedig olyan objektumok jöhetnek létre a játékon belül, mint fák, bok-rok, hegyek vagy éppenséggel épületek.

A videójáték egy másik egyedisége abban rejlik, hogy a randomizáltan lekép-zett világban éghajlati tulajdonságnak megfelelő biomok képezhetőek le. A Minecraft legfrissebb patch-jében (1.16) négy új biom jött be, ezzel kiegészítve az eddigi számot 79 különböző biomra, amelyeken 
változhat az időjárás és egymást követik az éjszakák illetve a nappalok.

Fontos tudni továbbá azt is, hogy a Minecraft azon felül, hogy az építést szolgálja rendelkezik egy ún. túlélő (survivor) és hardcore móddal, a kreatív mód mellett. A túlélő mód és a kreatív mód között pedig lényegi különbségek vannak jelen (Short, 2012; Minecraft Wiki, 2020).

A túlélő módban élőlényeket találhatunk, amelyek között megtalálhatóak barátságos (például: bárány, nyúl stb.) és ellenséges ágensek (például: fosztogató, csontváz-ijász, pók, zombi stb.), illetve olyanok is, amelyek támadás után válnak ellenségessé (például: farkas). Emellett túlélő módban a játékosnak gondoskodnia kell a karakteréről, ugyanis az nem megfelelő életkörülmények között képes meghalni, viszont az állapot nem végleges, ugyanis képes újjáéledni. A hardcore módban viszont a játékosnak nincs lehetősége újraéledni és a játék a karakter haláláig tart, így az egy nehezített túlélő mód. Ezzel szemben a kreatív módban teljesen a kreatív alkotás a játékos feladata. Minden blokktípussal rendelkezik és a kreált világban a játék „fizikai” törvényét átlépve képes repülni, amivel könnyebbé válik számára a magasabb épületek megé-pítése (Minecraft Wiki, 2020).

Végül szeretnénk szót ejteni a játék kollaborációs lehetőségéről, ami mind offline, mind online módon elérhető. Amennyiben egy hálózaton találhatóak a számítógépes eszközök, akkor a felhasználók képesek együtt, ugyanabban a világban játszani, ám ha a LAN lehetôségek nem állnak rendelkezésre, akkor a videójáték egyedi, online szerverek létrehozását is támogatja (Minecraft Wiki, 2020).

Összességében tehát elmondható, hogy a játék alapvetően a gyerekek kedvencévé válhat, amelyben kiélhetik kreativitásukat, de akár az idősebbek számára is kikapcsolódást jelenthet. Lehetőségeinek köszönhetően, pedig hamar az oktatás színterére is bekerült ezzel segítve a tanulók számára a tananyag elsajátítását.

\section{A Minecraft oktatási lehetőségei}

A Minecraft szinte minden órán felhasználható és ez annak is köszönhető, hogy 6 éves kortól egészen 18 éves korig alkalmazható, a többi pedig már csak a pedagógus kreativitásán múlik. A videójáték könnyű alakíthatósága és körbejárhatósága miatt remekül alkalmas oktatásra. Ezt bizonyítja természettudományos tantárgyakban való felhasználhatósága is, amelyről Short (2012) is beszámolt. Short (2012) a biológia órák vonatkozá-sában írja le az emberi test mintájára megalkotott világot, amelynek segítségével a szervekkel, de akár a biológiai lebontó folyamatokkal is megismerkedhetnek a tanulók, mindez pedig a Minecraft rendkívüli szabadságának köszönhető. Szót ejt emellett az ökológia órákon való alkalmazhatóságról is, mivel a videójáték (ahogyan a fentiekben említettük) megannyi a valóságban is megtalálható biommal rendelkezik. Ez a lehetőség különösen olyan osztályoknál lehet igazán hasznos, ahol nincs lehetőség különböző 
erdőfélék, faszintek bemutatására. Azonban az sem kizárt, hogy a pedagógus a Minecraft segítségével kirándulást szervezhet diákjainak a sivatagba vagy akár az Északi-sarkra (Short, 2012). Tehát megállapítható, hogy amennyiben a pedagógus ismeri a Minecraft videó-játékot, kizárólag a képzelete szabhat határt az óratartásnak. Nem lehetetlen egykori csata helyszíneinek újraépítése, majd körbejárása, kémia órákon a TNT robbanási folyamatának megismerése, de akár a fizika törvényeinek elsajátítása sem a Minecrafton keresztül. Annak köszönhetően, hogy ennyi pedagógus vette észre a Minecraftban rejlő lehetőségeket szerveződés indult be, aminek a Minecraft Education lett az eredménye. Azon kívül, hogy maga a portál, így egy óra tervekkel teli könyvtárat biztosít a tanárok számára szinte minden korosztályban és tantárgyban, egy különleges oktatási moddal is szolgál. Azonban felmerülhet a kérdés, mik is azok a „modok”.

A modok, avagy a modification-ök, olyan funkciók, amelyekkel a játékban változtatások érhetőek el. Jelen esetben ez a videójáték még inkább oktatásra alkalmazhatóságát segíti elő. Ezen oktatási mod segítségével a pedagógus képes kontrollálni diákjait, ha kell elteleportálni őket a megfelelő helyekre vagy éppenséggel blokkokkal ellátni őket, így teljes mértékben szabályozva az órát a virtuális világon belül is (Short, 2012; MinecraftEDU, 2020). Viszont számolnunk kell azzal a ténnyel is, hogy a videójáték és ezen felül az oktatási mod is költségekkel jár. A gyerekek mindegyikének, illetve az oktatónak egyaránt rendelkeznie kell a szoftverrel, és a pedagógusnak az oktatási moddal is. Emellett fontos tudni továbbá azt is, hogy a Mojang egy Minecraft demóval is szolgál, amelynek kipróbálása ajánlott, amennyiben komoly az érdeklődés. Jelen kutatásban emiatt a financiális tényezők miatt a játék demó verziója került felhasználásra.

\section{A kutatás bemutatása}

A szakirodalom álláspontjai alapján a kutatási hipotéziseink a következők voltak:

1) A számítógéppel végrehajtott óra ugyanannyira lesz eredményeiben sikeres, mint a hagyományos keretek között megvalósított tanóra (MinecraftEDU, 2020).

2) A motiváció értékének a tekintetében nem lesz szignifikáns különbség a kontroll és a kísérleti csoport között (Sitzmann, 2011; Pásztor, 2013; Wouters és mtsai, 2013).

A kutatás során két 3. osztályos (8-9 éves tanulók) csoport került összevetésre. Az egyik csoport esetén igyekeztünk nélkülözni az IKT eszközöket, ezért ott a diákok nem használták őket, míg a másik csoport esetében teljesen bevonódtak ezen eszközök használatába (átírós). A számítógépes órán való részvételhez a szülőknek/gondviselőknek hozzá kellett járulniuk. A hagyományos módszerekkel megvalósuló órán 29 gyerek vett részt, míg a számítógépekkel végrehajtott órán 16 
gyermek. Ennek oka a hiányzók magas száma volt.

A foglalkozások tematikája a pixel art köré rendeződött, így 2-2 rajz órát vett igénybe, mivel a foglalkozások 90 percesek voltak. Szünetet a gyerekek nem igényeltek. Az órák során végig ugyanazon feladatok kerültek végrehajtásra, kizárólag az eszközökben volt eltérés. Az előkészítő szakaszban először az óra témájának feltárása történt, ezt követte egy párkeresős játék, majd egy rövid motivációs beszélgetés. Ezután jött egy játék, amely során a gyerekeknek el kellett dönteniük, hogy az adott képen pixel art vagy hagyományos gépi fotó van-e, végül a szakaszt a valós térben való formaalkotással zártuk legók segítségével. Célkitűzés gyanánt a pedagógus ismertette a feladat technikáját. A következő lépésként megtörtént a munkafolyamat közlése, majd a követelmények átbeszélése. A munkafolyamat során folyamatos korrekció történt mindkét esetben, végül a tanulók közremúködésével megtörtént az értékelés a követelmények alapján:

- helyes technika (feleljen meg a pixel art fogalmi definíciójának az alkotás)

- megfelelō eszközhasználat (a kontroll csoport esetében színes ceruza helyes használata, a kísérleti csoport esetében a számítógép és a videójáték megfelelő iskolai használata)

- tiszta munka

Az elsajátított tananyag sikeressége az elkészült alkotások felé támasztott köve- telményeink szerint került értékelésre, továbbá a gyerekek véleményéről, hangulatáról egy rövid kérdőívvel (5 fokú Likertskála) szereztünk visszajelzést.

\section{Eredmények}

Mivel a kutatás során mindkét osztály teljesítményét ismertük (korábban tartott foglalkozások alapján), azt tudjuk elmondani, hogy munkájuk a szokásos színvonalról árulkodott. Rajzaikban igyekeztek megfelelni a követelményeknek és életkori sajátosságaiknak megfelelően ábrázoltak. Azt azonban mindenképp meg kell említenünk, hogy a videójátékozó osztálynak nehezebb dolga volt az alkotást illetően. A körüljárhatóság egyszerre volt pozitívum és negatívum számukra. Pozitívum a végeredményben rejlett, ugyanis az így jóval látványosabb volt, a negatívum pedig abban, hogy a gyereknek a blokkok 3D-és mivolta miatt muszáj volt térben dolgozniuk, ami nem mindenkinek ment ugyanolyan könnyen. Mindezen nehézségek ellenére, azonban mindkét osztály a követelményeknek megfelelően teljesített, ugyanis mind a hagyományos, mind a számítógépes fog-lalkozáson az óra elérte a célját és a diá-kok elsajátították a tananyagot, így első hipotézisünk beigazolódott.

Kutatásunk során továbbá a kis mintára és a gyerekek fiatalkorára való tekintettel egy rövid, általunk készített kérdőív került felhasználásra, melynek eredményeit a 1. táblázat és az 1. ábra szemlélteti. 
Az átlagértékek alapján elmondható, hogy a két csoport között mintázatbéli hasonlóságok vélhetőek felfedezni. A legnagyobb különbség a motiváció átlagértéke között volt megtalálható, ahol a videójátékozók értek el nagyobb eredményt, azonban ez csupán tizedes értékekben jelent meg, amelyek nem tekinthetőek számottevően nagy eltérésnek.

1. táblázat. A videójátékozók és a nem videójátékozók átlagértékei a kérdöivre adott válaszaik alapján. Forrás: Szerzộk.

\begin{tabular}{|c|c|c|c|c|}
\hline \multirow{2}{*}{ KÉRDÉS } & \multicolumn{2}{|c|}{ HAGYOMÁNYOS (N=29) } & \multicolumn{2}{|c|}{ SZÁMÍTÓGÉPES (N=16) } \\
\hline & ÁtLAG & SZÓRÁS & ÁtLAG & SZÓRÁS \\
\hline Hogy érezted magadat az órán? & 4,66 & 0,48 & 4,69 & 0,48 \\
\hline Mennyire tetszett az óra anyaga? & 4,52 & 0,74 & 4,75 & 0,45 \\
\hline Hogyan értékeled a tanitó órai munkáját? & 4,83 & 0,38 & 4,81 & 0,4 \\
\hline Mennyire érezted magadat aktivnak az órán? & 4,1 & 0,98 & 4,13 & 0,72 \\
\hline Mennyire tartottad érdekesnek az óra témáját? & 4,55 & 0,74 & 4,56 & 0,81 \\
\hline Mennyire vagy elégedett a munkáddal? & 4,17 & 1,14 & 4,13 & 0,72 \\
\hline Mennyire tudtad gondolataidat megosztani az órán? & 3,9 & 1,26 & 3,88 & 0,62 \\
\hline Mennyire érdekelt az óra témája? & 4,48 & 0,83 & 4,56 & 0,81 \\
\hline Késziteni fogsz-e késóbb hasonló alkotást? & 4,38 & 0,98 & 4,44 & 1,21 \\
\hline Mennyire értetted az óra feladatát? & 4,9 & 0,31 & 4,81 & 0,4 \\
\hline Milyen volt az óra hangulata? & 4,55 & 0,63 & 4,56 & 0,51 \\
\hline
\end{tabular}

1. ábra. A videójatékozók és a nem videójátékozók átlagértékeinek összehasonlitása a kérdöiure adott válaszaik alapján. Forrás: Sz̧erző̉k.

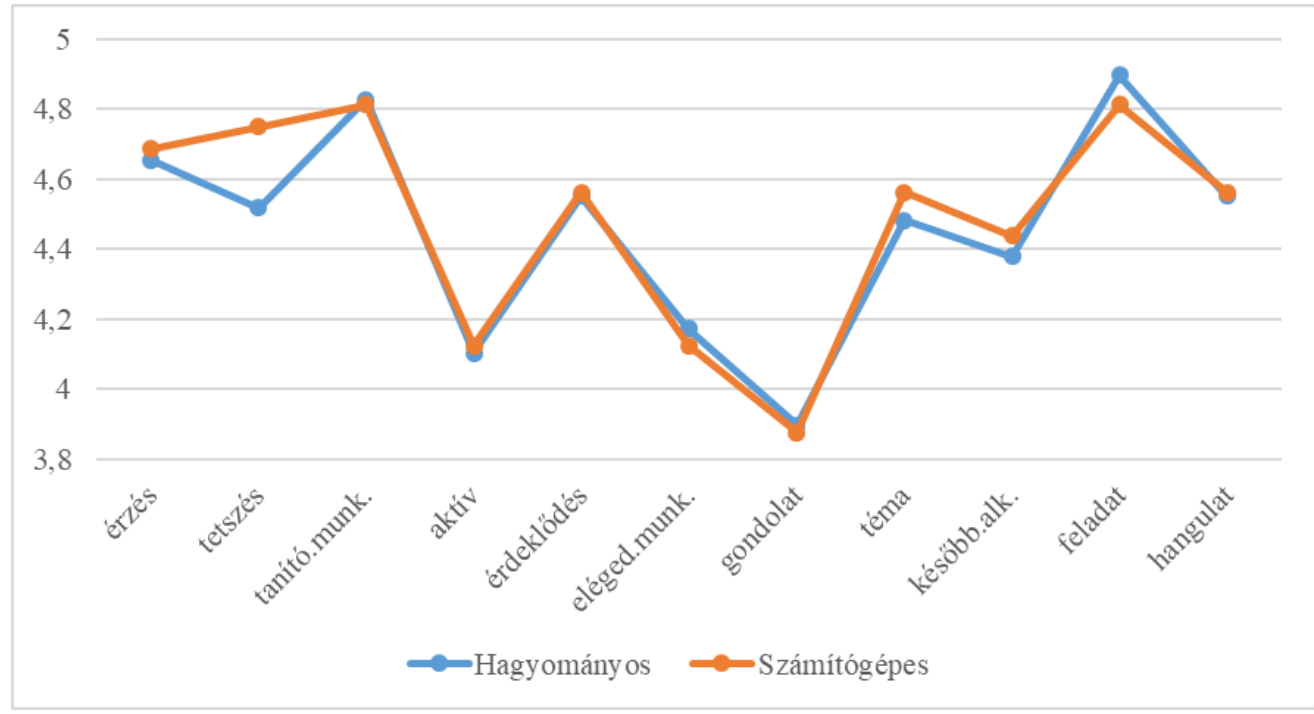


Mind a videiójátékozók, mind a nem videójátékozók 4,5 feletti átlagértéket mutatott az órán való hangulat, a tananyag tetszése, a tanító munkája, az óra témájának érdekessége és az óra feladatának megértése szempontjából, sőt az előbbiekben az óra feladatának megértése esetében volt az a tényező, ahol mindkét csoport a legmagasabb átlagértéket érte el (hagyományos órán 4,9-es, míg a számítógépes órán 4,81-es érték volt tapasztalható).

Továbbá kimagasló volt a videó-játékozók válaszai között a tanító munkájának értékelése, ami szintén 4,81-es átlagértékkel bírt. Az órákon a legalacsonyabb átlagértéket mindkét csoportban a „Mennyire tudtad gondolataidat megosztani az órán?" kérdés érte el (hagyományos órán 3,9-es, a számítógépes órán 3,88-as átlagértéket mutatkozott osztályszinten). Ennek okát a magas osztálylétszámban láttuk, illetve a rendelkezésre álló idő hiányában, ugyanis az új technika megtanítása több frontális tanítói közlést igényelt egy általános, fantáziafejlesztő rajz órához képest (1. táblázat és 1. ábra).

A szórás tekintetében többnyire egységes eredmények születtek és nem mutatkozott nagy szórás különbség még a csoportokon belül sem. Három kérdés esetében azonban viszonylagosan magasabb szórás mutatkozott. A "Mennyire vagy elégedett a munkáddal" 1,14-es, míg a "Mennyire tudtad gondolataidat megosztani az órán?” kérdés esetében 1,26-os érték volt fellelhető a nem videójátékozók csoportjában. Az első kérdésre adott szórás okát az osztály önkritikájában látjuk, ugyanis tapasztalataink szerint rendkívül kritikusak a munkájukkal szemben. A második kérdés esetében a magas osztálylétszámot láttuk okként, mivel a 29 fős osztálylétszám túlságosan nagy ahhoz, hogy kellő mennyiségû minőségi időt tölthessen el a pedagógus tanítványaival. A videójátékozóknál a „Készíteni fogsz-e később hasonló alkotást?" kérdésnél volt nagyobb szórás $(1,21)$. Ennek magyarázatát két okban látjuk. Egyrészről maguk a tanulók is megjegyezték azt, hogy nem mindenki számára elérhető a videójáték, így erre a válaszra többnyire az 1-es értékkel feleltek, ám azt mondták szívesen alkotnának újra a Minecraftban. Másrészről megosztó is volt a videójátékozós óra, ugyanis a lányoknak közel sem nyerte el annyira a tetszését a játék, mint a fiúkét.

Az eredményeink alapján ezért összességében elmondható, hogy a gyerekek a visszajelzéseik alapján élvezték a tanórákat, legyen az hagyományos vagy éppen számítógépes. A motiváció mérésének rendkívüli komplikáltsága, pedig még inkább torzíthatja az eredményeinket, viszont megállapítható, hogy a videójáté-kok motivációs csodája nem olyan jelleg-zetes, mint azt a hiedelem tartja (Sitzmann, 2011; Pásztor, 2013; Wouters és mtsai, 2013), azonban a videó-játékokkal való oktatás teljes mértékben lehetséges és járható útnak bizonyult kutatásunk során. 


\section{Konklúzió és limitációk}

Kutatásunk során célul tűztük ki azt, hogy megvizsgáljuk a videójátékokkal való oktatás lehetőségeit és azt kísérleti jelleggel teszteljük. Ennek érdekében a Minecraft játékkal hajtottuk végre a munkát, mivel a videójáték sajátosságai megfeleltek az oktatási játékok követelményeinek (Pásztor, 2013), így az megannyi lehetőséget adott az oktatásban való felhasználhatóságra.

Eredményeink több ponton is megerősítették a szakirodalom álláspontjait. Mivel mindkét óra sikeres volt és elérte oktatási, nevelési és fejlesztési céljait, így a videójátékokkal való oktatás relevanciáját mi is meg tudtuk erősíteni. A motiváció tekintetében szintén megerősítésre került az, miszerint a kontroll elvesztése meg-fosztja a videójátékozót a nagy motivációs élménytől. Nem szabad viszont elfeledkeznünk arról sem, hogy a vizsgált csoportok motivációjának mérése rendkívül problémás, hiszen gyerekekről van szó. További limitációnk még emellett az, hogy utóbbi tényező vizsgálatának esetében kérdőíves eljárást alkalmaztunk, ami szintén hiányosságokat vethet fel. Mindezek okául ezért számolnunk kell azzal a lehetôséggel is, hogy a magas motiváció mögött inkább a pedagógus iránti szeretet áll, mint a videójátékozás élménye. Az előzőekben említett limitációk megoldásaképpen jól működhet, ha még egy pedagógus segítségét is kérjük a kísérlet pontosabb eredményeinek érdekében, ugyanis nekünk erre a kutatás folyamán nem volt lehetôségünk. Végül mindenképp hasznos volna egy olyan motivációs mérőeszközt találnunk, ami kisiskolás gyermekeknél is jó megbízhatósággal bír. Mindazonáltal elmondható, hogy a kísérlet teljes mértékben egy újszerû, de annál inkább előremutató oktatási irányt szemléltet. Tapasztalataink szerint a 21. századi diáknak, pedig igénye van a digitális eszközökre a mai oktatásban, hiába bizonyulnak az IKT eszközök éppen csak ugyanolyan sikeres-nek, mint a hagyományos eszközök. Mint ahogyan már mi sem az egykori kódexekből nyertük tudásunkat, úgy a mai gyermek sem vágyik ugyanarra, mint ami az öregebb generációknál mutatkozott sikeresnek. Éppen ezért úgy véljük a világ változásaira az oktatásnak reagálnia kell, ugyanis a gyors fejlődés miatt talán még soha nem volt ennyire szükség az innovatív gondolkodásra mint most.

\section{Irodalom}

Bányai, F. és Fülöp, M. (2015). A videojáték-használat pszichológiai megközelítései. IMÁGÓ Budapest, 4(4), 6-26.

Deci, E. L. és Ryan, R. M. (2000). The "what" and "why" of goal pursuits: Human needs and the selfdetermination of behavior. Psychological Inquiry, 11, 227-268

Pásztor, A. (2013). Digitális játékok az oktatásban. Iskolakultúra, 9, 37-48.

Kárpáti, A. (2003). Az informatika hatása az iskola szervezetére, kommunikációs és oktatásinevelési kultúrájára. $\quad U_{j}$ 
Pedagógiai Szemle, 53(5), 24-37.

McGonigal, J. (2011). Reality Is Broken: Why

Games Make Us Better and How They Can

Change the World. New York: The Penguin Press.

Ryan, R.M., Rigby, C.S. és Przybylski, A. (2006).The Motivational Pull of Video Games: A Self -Determination Theory Approach. Motiv Emot, 30, 344-360 DOI: $\underline{10.1007 / \mathrm{s} 11031-006-9051-8}$

Short, D. (2012). Teaching Scientific Concepts using a Virtual World Minecraft. Teachingscience, 58(3), 55-58.

Sitzmann, T. (2011). A meta-analytic examination of the instructional effectiveness of computer-based simulation games. Personnel Psychology, 64, 489-528.

Wouters, P., van Nimwegen, C., van Oostendorp, H. és van der Spek, E., D. (2013). A meta-analysis of the cognitive and motivational effects of serious games. Journal of Educational Psychology, 105(2), 249-265.

Minecraft Wiki. (2020). Elérhető: https://minecraft.gamepedia.com/Mi necraft Wiki

MinecraftEDU. (2020). Elérhető: https://education.minecraft.net/ 